\title{
Correction to: The cost effectiveness of personalized dietary advice to increase protein intake in older adults with lower habitual protein intake: a randomized controlled trial
}

Ilse Reinders ${ }^{1}\left(\right.$ Marjolein Visser $^{1} \cdot$ Satu K. Jyväkorpi ${ }^{2} \cdot$ Riikka T. Niskanen $^{2}$. Judith E. Bosmans ${ }^{1}$. Ângela Jornada Ben ${ }^{1}$. Ingeborg A. Brouwer ${ }^{1}$. Lothar D. Kuijper ${ }^{1}$. Margreet R. Olthof ${ }^{1} \cdot$ Kaisu H. Pitkälä ${ }^{2}$. Rachel Vijlbrief ${ }^{1} \cdot$ Merja H. Suominen ${ }^{2} \cdot$ Hanneke A. H. Wijnhoven ${ }^{1}$

Published online: 14 December 2021

(c) The Author(s) 2021

\section{Correction to: European Journal of Nutrition https://doi.org/10.1007/s00394-021-02675-0}

In section "Change in 400-m walk time", second sentence should read as

A intervention effect in the same direction was observed in PROT + TIMING, but not statistically significant; $-4.9 \mathrm{~s}$ (95\% CI, -14.5 to 4.7 ) (Table 3 ).
Open Access This article is licensed under a Creative Commons Attribution 4.0 International License, which permits use, sharing, adaptation, distribution and reproduction in any medium or format, as long as you give appropriate credit to the original author(s) and the source, provide a link to the Creative Commons licence, and indicate if changes were made. The images or other third party material in this article are included in the article's Creative Commons licence, unless indicated otherwise in a credit line to the material. If material is not included in the article's Creative Commons licence and your intended use is not permitted by statutory regulation or exceeds the permitted use, you will need to obtain permission directly from the copyright holder. To view a copy of this licence, visit http://creativecommons.org/licenses/by/4.0/.

The original article can be found online at https://doi.org/10.1007/ s00394-021-02675-0.

Hanneke A. H. Wijnhoven

hanneke.wijnhoven@vu.nl

1 Department of Health Sciences, Faculty of Science, and The Amsterdam Public Health Research Institute, Vrije Universiteit Amsterdam, De Boelelaan 1105, Room O-533, 1081 HV Amsterdam, The Netherlands

2 Department of General Practice and Primary Health Care, and Helsinki University Central Hospital, Unit of Primary Health Care, University of Helsinki, Helsinki, Finland 